\title{
METHODOLOGICAL BASIS OF DEVELOPMENT OF RESEARCH COMPETENCE OF SECONDARY SCHOOL STUDENTS IN THE NETWORK RESEARCH COMMUNITY
}

\author{
Natalia Bezrukova, Anatoly Bezrukov, Krasnoyarsk State Pedagogical University named after \\ V.P. Astafiev, bezrukova@kspu.ru
}

\begin{abstract}
In this study, we analyzed the development of research competence and the creative thinking of secondary school students in rural areas of Russia. We have found that students struggle with critical thinking, and it is rare when students are able to think creatively. Therefore, we have suggested a research network community as a possible solution to this problem by uniting teachers, post-graduate students and undergraduates of the university. Teachers and students of the secondary schools were proposed with an "information-and-activity concept" as a way of their learning problems solution. We have found that a network research community is supportive for the students, using an information-and-activity concept, to develop in them required research competences. The authors have identified a community model in respect to the information-and-activity concept. We have tested the effectiveness of a network community model in an experiment at rural secondary schools of Krasnoyarsk region. Usage of remote sensing has been effective in critical thinking improvement.
\end{abstract}

UDC Numbers: 373 - 37.01/.09; 37.02, DOI: 10.12955/cbup.2013.28

Key words: methodology, research competence, remote technologies, network community

\section{Introduction}

The success of the long-term economic development plan depends on it implementation and a country's social sphere. Moreover, the country's social sphere depends on how all subjects involved in various economic and social relations will be able to maintain their competitiveness. The personal qualities to take initiative and ability of the individuals to think creatively are the important conditions for being competitive. So there is dire need to equip the younger generation with the complex but necessary knowledge and universal methods of cognition and practical activity. It would make the younger generation up-to-date research competent. The individuals would have deep theoretical meaning and practical relevance.

The conditions for the improvement in the research competence of students are present in the Russian secondary school education system. In particular, the assessment of the effectiveness of the school activities includes the number of student-winners of subject competitions and student scientific conferences.

Obviously, schools located in large cities with research centers and universities have got advantages. However, a significant percentage of the total number of secondary school students belongs to the 
rural areas of the Russian "heartland". The problem of development of their creative thinking and research competence is particularly acute for Siberia and the Far East. The authors of this paper consider networking educational technologies as a promising means of solution to the problem.

\section{Literature review}

Russian teacher-researchers had shown their interest in developing the research skills in the students in 1920s. In the 1960s, in connection with the development of the problem approach to education, the teacher-researchers and methodologists revised the content of all school subjects in order to provide recommendations for the creation of the problem situations and resolve them together with the students at the lessons. Furthermore, the investigations were widely used to solve the problems in the 1970-80s (Ivankova, 1969; Gurevich, 1979). During the same period, also in the 1990s, many studies revealed features of research skills formation and development student's creative activity on substantive content (chemistry, physics, history and so on) had been performed (Lerner, 1982; Orzshekovsky, 1998 and many others). However, due to the high information saturation of school subjects the teachers have to apply, mainly, reproductive practices. The assimilation of "ready-made knowledge" leads to the fact that students not only lose their studied theoretical concepts but also their model character. As a result, along with the assimilation of "ready-made knowledge", students also acquire that type of thinking. The researchers need to create the conditions for individual development of students and teach them about the perceptions of the reality in surroundings. Students should have an understanding about the general mechanisms of cognition and the role of logical and intuitive components, in this process, and the model character of obtained knowledge as well. The assimilation of the theory of knowledge by students can not be implemented without their own experience of nomination and hypothesis testing, modeling and confirm their solvency, as well as without identifying the borders of the use of the models.

The analysis of information sources has shown the interest in the research skill formation of the students. The research skills of the students increase in the periods of reforms in school education. Social and economic changes during the $20^{\text {th }}$ and $21^{\text {st }}$ centuries have caused the change of value orientation in the Russia. Stratification of the Russian society into social groups with different level of living, a wide range of moral orientations and behaviour norms, in the absence of a unifying idea, aggressiveness and contradictions of mass media, resource insufficiency of the life components led to a remarkable decline in the level of education of the Russians. The problem of the Russian is the growing gap between the level of graduate preparations of urban schools and rural ones. The Russian education problem is also a growing gap between the level of graduate preparation of urban schools and rural ones. It is not surprising, therefore, that over the last decade, a lot of researches, dealing with the theory and practice of the development of student research activities. These researches took into account the changing conditions of the Russians (Leontovich, 2001; Obukhov, 2006; Vikhoreva, 2009; Semchuk, 2006 and many others).

There are some examples, in the psychological and pedagogical literature and Internet, of the application of remote sensing technologies for the development of student creative abilities. The Fund of noncommercial programs "Dynasty" deserves great attention. The Fund activity is to search and support the talented students, their ideas and projects in the field of natural and social sciences through the funding of a series of projects, scholarships. The analysis of opportunities of remote sensing technologies in the training of gifted children was carried out by Mozshaeva et al. (2005). However, it is necessary to integrate systematically the efforts of university and school teachers to provide training to graduates so that become capable of finding non-standard solutions. 
The authors of this paper, in 2010, had organized the network research community uniting the teachers and students of higher school and secondary schools. The network community, in 2011, implemented the project "The young naturalist school". In the project framework the student researches on subprojects "Algae and fungi of natural ecosystems", "Nucleic acids"; "Nature and ecology of the Krasnoyarsk region"; "Remote astronomical school" were organized. More than three hundred students of rural secondary schools, during this project, took part in the work of the community. The analysis of the project implementation allowed identifying the organizational and pedagogical conditions for functioning of the network research community (Bezrukova et al., 2012). Since the project was short-term so the count on steady growths in the spectrum of the personal characteristics of the students was not possible. However, its results allowed us to make a conclusion about the availability of the idea of the network research community. In general, it became obvious that the decision of the problem requires the using of the system approach.

\section{The information-and-activity concept and the model of the development of student research competence in the network community}

The term "scientific and research community of adults and children" is interpreted as a form of organization of research activities, i.e. the relationship between students and teachers as a collective subject of research activities. The main difference between the content of this notion and the classical understanding of the term "research community" is that it is a temporary structural unit for the solution of not only cognitive but also for the pedagogical problems (Vikhoreva, 2009). It should be noted that, with respect to secondary school students, we can speak only about the study-research activities. Obukhov (2006) writes that the student research activity is a process of interaction between the teacher and the student to find a solution to the unknown, in the course of which the translation of cultural values is carried out. The main result of this activity is the development of student research position to the world. In this context the main function of academic study involves the creation of conditions for creative knowledge, development of needs and capacity for self-cognitive activity, improvement of the educational motivation and activation of a personal position in the educational process.

The information-and-activity concept of research competence development of the secondary school students in the network community includes leading ideas, approaches, and principles. The leading ideas are that the joint training-and-research activity is the certain commonality that occurs in the study process and leads to the formation of general semantic field for all the participants that provides further self-regulation of their individual activities. The information-and-activity approach is the main tool for implementation of the above processes. The leading approaches are the system approach and the information-and-activity approach. It should be noted that the information-and-activity approach is the development of information approach to education. According to this approach the informationand-activity learning is a way of organizing the joint activities of the teacher and the student based on the wide using of information and communication technologies. The teacher, during this process, provides the motivation and the necessary conditions for various types of student research activities through the introduction into the traditional educational system the innovative pedagogical technologies, based on the idea of humanization, personalization and differentiation of teaching, open and active information exchange between the student and the various information sources and independent cognitive activities of students (Bezrukova, 2006).

The above ideas and approaches are specified in the form of principles for the organization and functioning of the network research community. The most important of which are the motivation, the equal cooperation, the information humanity and the accessibility. Thus, the principle of accessibility 
encourages developers to the fact that the list of topics and research plans is developed in the context of scientific researches which are performed by the scientific and pedagogical workers of the university, taking into account the level of educational opportunities of secondary school students, as well as the level of material and technical support of research, which secondary school can really provide. The principle of information humanity involves designing of training taking into account the information foundations of education, based on psycho-physiological peculiarities of perception, processing, storage and playback of information by a person.

The information-and-activity model corresponding to the concept includes the target component, the content-structural component, the organization-and-technology component, the procedural-activity component and the effective-and-evaluation component. The target component reflects the order of society to the education system. It encompasses the training of secondary school graduates to create research competence and innovative thinking.

The content-structural component refers to the creation of information-and-activity environment, as a set of conditions for the organization of productive educational and research activities of secondary school students, undergraduate and postgraduate students of the university. It includes the system of providing the development of students' research skills. In this system the development of university teachers is ensured for their professional competence in the field of the network technology possibilities. In this way they play vital role in the development of the research competence the students. The system provides the development of the competence of secondary school teachers both in the field of network technology possibilities and in the directions of future joint research. There is an important role of training system of masters and post-graduate students in the field of network technologies.

The organization-and-technology component includes the system ensuring the normative-legal interaction between the university and the secondary schools. It involves in the community in providing the system of technical support of interaction between the community participants. This system ensures the interaction schedule.

The procedural-activity component defines the stages of the community research activities in reading on-line lectures, conducting the research on the selected direction, organization of consultations and webinars to discuss the results, processing and presentation of the results of research on the Internetconferences. The Figure 1 shows the scheme of research mini-groups formation and the interaction in a group.

Figure 1: The scheme of formation of research mini-groups and the interaction in a group

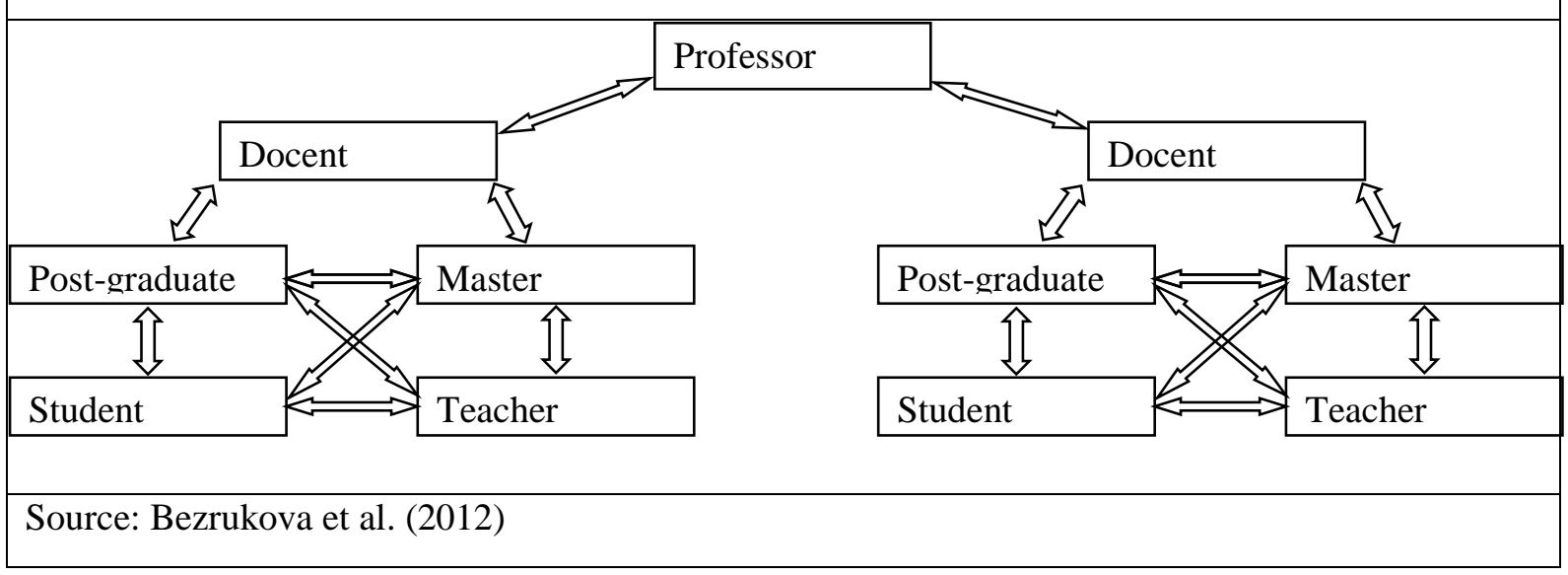


The effective-and-evaluation component provides the assessment of the level and dynamics of the research competence development. The assessment is carried out with use of the developed criteria and indicators.

According to the content-structural component the information-and-activity environment is developed. In particular, the system providing the development of student research skills contains the list of topics and research plans in the context of scientific research, which is performed by the scientific and pedagogical workers of the university. For example, in 2013, in our network community, we are working in the following directions: "The Russian language in the Krasnoyarsk region" , "Folklore of the East-Slavic peoples living in the Krasnoyarsk region", "Protected natural territory of the Krasnoyarsk region ", "Higher plants of the Krasnoyarsk region", and "The history, language and culture of the Germans living in the Krasnoyarsk region". As for the systems ensuring the development of professional competence of community adult members the corresponding programs and didactic materials are developed. The use of network technologies, for the development of research competence in students, to foster the competence of masters and post-graduate students is underway. It is necessary to develop the appropriate modules in the syllabus of the discipline "Information technologies in professional activity" and so on. As for the system providing the technical support of interaction between the community participants there is a set of special computer programs available at the software market, for example Open Meeting, Adobe Connect.

\section{The methods of analysis of the model effectiveness}

At this stage the proposed model is tested in the Krasnoyarsk region districts. The psychological studies are conducted to identify the impact of participation in the network community work on the development of student personality. The achievement of the required quality of works is measured by objective test procedures. Test of verbal creativity (Mednich, 1969) in the adaptation made Galkina et al. (1991) is used for the creative potential diagnostics. The personal characteristics - factors of creativity are studied using Creativity Assessment Packet (Williams, 1980) in modification made Tunik (2003). The Renzulli questionnaire (Renzulli, 1971) in modification made by Tunik (2004) is used for the diagnostics of students' creative thinking. The student research works are analyzed by experts.

\section{Conclusion}

The main characteristics of the developed model are that it is independent of the particular implementation in the teaching of educational discipline and educational institutions. The model also accounts for the integrity because all components are interconnected and operate to achieve final result. So a stable relationship has been observed between the components that change according to external conditions. The model takes into account an existence of invariant (the purpose and the principles of model design, the interaction forms) and variable (the directions and methods of researches) parts.

\section{Acknowledgement}

The investigation is performed with the financial support of the Russian Humanitarian Scientific Foundation, The regional competition "Russian power will increase through Siberia and the Arctic ocean" - the Grant No. 13-16-24020 "Network research community as the environment of the development of creative thinking, the research competence of secondary school students", 2013. 


\section{References}

Bezrukova, N. P. (2006). Teorija i praktika modernizacii obuchenija analiticheskoj himii v pedagogicheskom universitete [Theory and practice of modernization of teaching analytical chemistry in Pedagogical University]. (Doctoral dissertation). Moscow, Russia: Moscow State Regional University.

Bezrukova, N. P., Timirgalieva, T. K., \& Bezrukov, A. A. (2012). Razvitie issledovatel'skoj kompetencii uchashhihsja $\mathrm{v}$ ramkah setevogo issledovatel'skogo soobshhestva [The development of the research competence of students in the network research community]. Fundamentalnie issledovania [Fundamental Research], 11 (4), 866-869.

Galkina, T. V., \& Alekseeva, L. G. (1991). Test Megnika kak metod diagnostiki kreativnosti i ego russkoayzichnij variant [Mednich's test as a diagnostic method of creativity and its Russian-language version. Psikhologicheskij analiz uchebnoy deaytel 'nosti [Psychological analysis of the training activities] (pp. 187-193). Moscow, Russia: IP RAN [Institute of Psychology, Russian Academy of Sciences].

Ivankova, N. V. (1969). Issledovatelskij metod v obuchenii [Research method in the learning]. Rostov-na/D, Russia: Pheniks [Phoenix].

Lerner, I. Y. (1982). Razvitie myshleniya uchashhixsya v processe obucheniya istorii: Posobie dlya uchitelej [The development of thinking skills of learners in the process of history teaching: book for teachers]. Moscow, Russia: Prosveschenie [Education].

Leontovich, A. V. (2001). Model nauchnoj shkoly i praktika organizacii issledovatelskoj deyatelnosti uchashihsya [Model of the scientific school and practice of organization of research activity of students]. Shkol'nye tehnologii [School technologies], 5.

Mednich, S. A. (2005). The associative basis of the creative process. Psychol. Rewiew, 2, 220-232.

Mozhaeva, G. V., \& Tubalova, I. V. (2005). Primenenie distancionnyx texnologij obucheniya dlya razvitiya tvorcheskix sposobnostej odarennyx detej [The use of distance learning technologies for the development of creative abilities of gifted children]. Otkrytoe i distancionnoe obrazovanie [Open and distance education], 1, 36-43.

Obukhov, A. S. (2006). Razvitie issledovatel'skoj dejatel'nosti uchashihsya [Development of research activity of students]. Moscow, Russia: Prometei [Prometey].

Orzhekovskij, P. A. (1997). Formirovanie u uchashihsya opyta tvorcheskoj deyatelnosti pri obuchenii ximii [Development of students ' creative experience in teaching chemistry ]. Moscow, Russia: IOSO RAO [Institute of General secondary education, Russian Academy of education].

Renzulli, J. S., \& Hartman R. K. (1971). Scale for rating behavioural characteristic of superior students. Exceptional Children, 38, 243-248.

Semchuk, N. M., \& Muxambetova A. B. (2006). Razvitie issledovatelskix umenij shkolnikov pri izuchenii ekologo - biologicheskix problem [Development of research skills of the students in the study of environmental and biological problems]. Sovremennye problemy nauki i obrazovaniya [Modern problems of science and education], 2, 100-101. 
Tunik, E. E. (2003). Modificirovannye kreativnye testy Vil'jamsa [Williams's modified creative tests]. Sankt Peterburg, Russia: Rech' [Speech].

Tunik, E. E. (2004). Oprosnik Renzulli [Renzulli's questionnaire]. Shkol'nyj psiholog [School psychologist], 4.

Vikhoreva, O. A. (2009). Pedagogicheskie usloviya realizacii issledovatelskoj deyatelnosti starsheklassnikov $\mathrm{v}$ dopolnitelnom obrazovanii [Pedagogical conditions of realization of research activity of senior pupils in additional education]. Vestnik ChGPU [Bulletin of the Chelyabinsk state pedagogical university], 9.

Williams, F. E. (1980). Creativity Assessment Packet (CAP). Buffalo, NY: D.O.K. Publisher. 